\title{
Occurrence of anatoxin-a(s) during a bloom of Anabaena crassa in a water-supply reservoir in southern Brazil
}

\author{
Vanessa Becker • Priscila Ihara • João Sarkis Yunes • \\ Vera Lúcia M. Huszar
}

Received: 12 March 2009/Revised and accepted: 18 May 2009 /Published online: 9 June 2009

(C) Springer Science + Business Media B.V. 2009

\begin{abstract}
Cyanobacterial blooms and the accompanying production of cyanotoxins are a serious global problem. Toxic blooms of Anabaena species are common in lagoons and reservoirs of southern Brazil. Worldwide, species of the genus Anabaena produce the majority of the known hepatotoxins (microcystins) and neurotoxins [anatoxin-a, anatoxin-a(s), and saxitoxins]. This report links a bloom of Anabaena crassa in the Faxinal Reservoir, the main water supply for the city of Caxias do Sul (400,000 inhabitants) in southern Brazil, to the occurrence of anatoxin-a(s) in the water. During the bloom period, the reservoir was strongly stratified, with higher temperatures and a deep anoxic hypolimnion. Two methods for sample concentration (direct and complete extraction) were tested, and direct extraction of samples proved to be more efficient. Water samples collected during the bloom showed $9 \%$ acetylcholinesterase inhibition at $50 \mathrm{mg} \mathrm{mL}$, corresponding to $0.61 \mu \mathrm{g}$ of anatoxin-a(s) per gram of lyophilized powder. At these
\end{abstract}

\footnotetext{
V. Becker · V. L. M. Huszar

Laboratory of Phycology, Museu Nacional do Rio de Janeiro,

Universidade Federal do Rio de Janeiro,

Quinta da Boa Vista s/no,

São Cristovão, Rio de Janeiro 20940-040, Brazil

P. Ihara $\cdot$ J. S. Yunes

Unidade de Pesquisa em Cianobactérias, Prédio da HidroquímicaInstituto de Oceanografia, Universidade Federal do Rio Grande, Campus Carreiros da FURG,

Rio Grande 96201-900, Brazil

\section{Becker $(\bowtie)$}

Water Resources and Sanitary Engineering Post Graduate Program, Instituto de Pesquisas Hidráulicas, Universidade Federal do Rio Grande do Sul,

Av. Bento Gonçalves 9500,

91501-970 Porto Alegre, Brazil

e-mail: becker.vs@gmail.com
}

concentrations, symptoms of neurotoxicity and mortality were not observed in tests with Swiss albino mice. Although the concentrations of anatoxin-a(s) in the Faxinal Reservoir were low, these results are important because this is the first record of the toxin for A. crassa. Furthermore, this cyanotoxin is not yet included in Brazilian legislation for drinking-water monitoring, because of the lack of information about toxicity levels and risk calculation for oral doses. The data presented here contribute to the basis for the future inclusion of this toxin in Brazilian legislation for drinking-water quality control, and for the development of analytical methods for this toxin.

Keywords Acetylcholinesterase Cyanobacteria Cyanotoxin $\cdot$ Subtropical

\section{Introduction}

Cyanobacterial blooms cause social, economic, and environmental problems. In Brazil, such blooms have been increasing in intensity and frequency, with cyanobacteria dominating throughout the year in many reservoirs (e.g., Beyruth 2000; Huszar et al. 2000; Calijuri et al. 2002; Bouvy et al. 2003; Vieira et al. 2005). Blooms may also cause aesthetic problems, deoxygenation, production of odor and taste in water, and, frequently, the formation of toxins (Whitton 1992). Cyanobacteria are capable of producing hepatotoxic peptides, neurotoxic alkaloids, and a wide spectrum of other selectively bioactive biotoxins (Carmichael 1992; Rapala 1998).

Cyanotoxins have received attention from researchers of water suppliers and human-health sectors because of: (a) the increase in numbers of toxic blooms in reservoirs; (b) the discovery of new toxins and their associated risks; and (c) the increase in cases of acute and chronic poisoning in 
domestic animals and in human beings (Molica et al. 2005). In Brazil, cyanotoxins have been reported in several studies: microcystins (Azevedo et al. 1994; Matthiensen et al. 2000; Minillo et al. 2000; Vieira et al. 2005; SoteroSantos et al. 2008; Ferrão-Filho et al. 2009), cylindrospermopsin (Carmichael et al. 2001), saxitoxins (Lagos et al. 1999; Yunes et al. 2003; Molica et al. 2005; Ferrão-Filho et al. 2009), and anatoxin-a(s) (Monserrat et al. 2001; Yunes et al. 2003; Molica et al. 2005). However, anatoxin-a has never been found at detectable levels (Molica et al. 2005; Colvara 2005). The genus Anabaena includes common filamentous bloom-forming cyanobacteria of world-wide distribution, and some species are able to produce toxins, such as hepatotoxins (microcystins) and neurotoxins [anatoxin-a, anatoxin-a(s), and saxitoxins] (Codd et al. 1997, Sotero-Santos et al. 2008).

Anatoxin-a(s) is a natural organophosphate that acts as a non-competitive inhibitor of acetylcholinesterase (AChE) activity, preventing it from hydrolyzing the neurotransmitter acetylcholine. The letter "s" corresponds to the characteristic symptom of salivation caused in vertebrates, mainly in doses close to $\mathrm{LD}_{50}$ levels $\left(20-40 \mu \mathrm{g} \mathrm{kg}^{-1}\right.$; Matsunaga et al. 1989). As a consequence, acetylcholine remains attached to the membrane receptors, resulting in continuous muscle stimulation. When respiratory muscles are also affected, death may occur by convolution, suffocation, and lack of oxygen in the brain (Matsunaga et al. 1989; Carmichael and Falconer 1993).

The method to estimate anatoxin-a(s) levels uses the AChE inhibition assay, which was originally designed to estimate organophosphate herbicides, but is also used with cyanobacterial bloom extracts. Monserrat et al. (2001) and Barros et al. (2004) used a complete sample extraction prior to assessing AChE inhibition; whereas Henriksen et al. (1997) and Molica et al. (2005) used a simplified extraction. Therefore, it is necessary to evaluate methods and to determine the best conditions for this enzyme assay.

Toxic blooms of Anabaena species are common in Brazilian aquatic environments, mainly in water-supply reservoirs and lagoons (e.g., Sant'Anna and Azevedo 2000; Monserrat et al. 2001; Yunes et al. 2003; Barros et al. 2004). The occurrence of anatoxin-a(s) has been reported from the United States, Canada, and Denmark (USEPA 2001). This toxin is mainly related to the deaths of dogs, birds, ducks, and other domestic animals caused by blooms of Anabaena lemmermannii (Henriksen et al. 1997) and A. flos-aquae (Mahmood et al. 1988; Cook et al. 1989). Toxic blooms of A. crassa (Lemmermann) Komárková-Legnerová are common in reservoirs of the city of Caxias do Sul (Frizzo et al. 2004). Cyclic blooms (spring and summer) of this species were observed between 2002-2004 in the Faxinal Reservoir, the main reservoir of the city (Yunes et al. 2005; Becker et al. 2008), which services approximately $63.3 \%$ of the population. In Brazil, there exists no record of neurotoxicity from anatoxin-a(s). However, there are possible indications of its presence in cases reported from the states of Rio Grande do Sul (Monserrat et al. 2001; Yunes et al. 2003) and Pernambuco (Molica et al. 2005), associated with blooms of A. spiroides Klebahn.

Here, we report the occurrence of the neurotoxin anatoxina(s)-like anticholinesterase (AChE) during a bloom of $A$. crassa in the water-supply Faxinal Reservoir, southern Brazil. We also compared and evaluated methods to extract the samples in order to assess the occurrence of anatoxin-a(s) by means of the AChE enzyme inhibition assay.

\section{Materials and methods}

Study site

Faxinal Reservoir $\left(29^{\circ} 05^{\prime} 00^{\prime \prime} \mathrm{S} ; 51^{\circ} 03^{\prime} 30^{\prime \prime} \mathrm{W}\right)$ is the main water-supply ecosystem for the city of Caxias do Sul (400,000 inhabitants), in subtropical southern Brazil (Fig. 1). The reservoir was constructed in 1992, lies at an elevation of $700 \mathrm{~m}$ a.s.l, and has a surface area of $3.1 \mathrm{~km}^{2}$. It is deep $\left(z_{\max }=30 \mathrm{~m}\right)$, warm monomictic, and mesotrophic

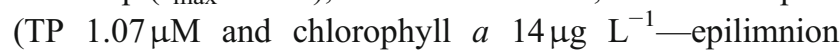
annual mean; Becker et al. 2008). The regional climate is temperate, without a dry season (type Cfa; Köppen 1936). The annual historical mean temperature, provide the full seasonal range, is $16^{\circ} \mathrm{C}$, and total annual rainfall ranges between 1,800 and $2,200 \mathrm{~mm}$.

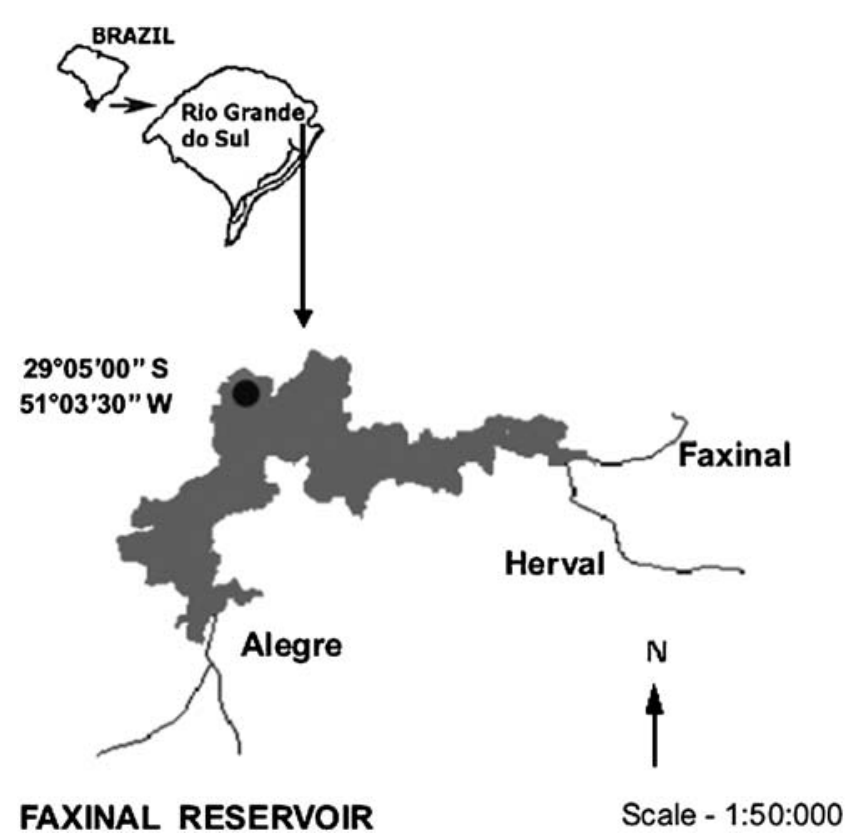

Fig. 1 Faxinal Reservoir showing the sampling station (filled circle) and the tributaries: Alegre, Herval, and Faxinal rivers 
Sampling

Water samples were taken during a bloom of $A$. crassa in January and February/2004. Sampling followed the protocols of the water company (SAMAE - Serviço Autônomo Muncipal de Água e Esgoto) algal monitoring program, at the surface, at the water-intake sampling station (Fig. 1). Vertical profiles of temperature, dissolved oxygen, $\mathrm{pH}$, and conductivity were measured with a Horiba model U-10 multiparameter probe, at $1-\mathrm{m}$ intervals from the surface to the bottom $(30 \mathrm{~m})$.

Samples for phytoplankton analyses were collected biweekly at the surface, with a Van Dorn bottle (2 L), at a fixed time (09:00 AM). Phytoplankton samples were fixed with neutral Lugol's solution. Samples for cyanotoxin analyses were collected with a plankton net $(25 \mu \mathrm{m}$ mesh size) to concentrate the material, and were immediately frozen at $-30^{\circ} \mathrm{C}$.

\section{Sample analysis}

Phytoplankton was counted with the aid of a Leica-DMIL inverted microscope (Utermöhl 1958) at $\times 400$ magnification. The units (cells, colonies, and filaments) were enumerated in random fields (Uhelinger 1964), and at least 100 specimens of the most frequent species were counted $(p<0.05$, Lund et al. 1958). The species of Anabaena was identified by descriptions from Kamárková-Legnerová and Cronberg (1992) and Komárek and Anagnostidis (1989).

\section{Anatoxin-a(s) analysis}

Anatoxin-a(s) was detected through either a direct extraction prior enzyme assay (Henriksen et al. 1997; Molica et al. 2005) as optimized by Barros et al. (2004), or through a complete sample extraction (Monserrat et al. 2001). In both cases, the determination of the AChE enzymatic activity used the methods recommended by Ellman et al. (1961) and their inhibition of $\mathrm{AChE}$ (acetylcholinesterase) as used by Barros et al. (2004). Lyophilization was done using the whole sample (water and cells) as collected in the reservoir and transported frozen to the laboratory. Lyophilization was run in MicroModulyo equipment (Edwards, UK) until the samples were completely dry.

The direct extraction was done by subjecting the lyophilized material to a single-extraction procedure to release the cell toxins. Different from the technique used by Henriksen et al. (1997) and Molica et al. (2005), we replaced the ethanol extraction of the cells by a simple process of sonification as developed by Barros et al. (2004). The procedure for the direct extraction is described below:

Direct extraction $50 \mathrm{mg}$ of lyophilized cyanobacterial cells was dissolved in $1 \mathrm{~mL}$ of distilled water of $\mathrm{pH} 3.3$ and sonified, on ice, for $1 \mathrm{~min}$ at $20 \mathrm{kHz}$ (Ultrasonic Processor Model GE 50). This suspension was then centrifuged for $5 \mathrm{~min}$ at $10,000 \mathrm{rpm}$ (Eppendorf 5415C, USA), and the supernatant was used in a concentration of $50 \mathrm{mg} \mathrm{mL}^{-1}$ in the enzyme (AChE) assays.

The complete sample extraction was done following the method of Barros et al. (2004). These authors divided the so-called indirect extraction into three procedures or phases: Extraction, semi-purification, and concentration, as described below:

Extraction $100 \mathrm{mg}$ lyophilized material was dissolved in $40 \mathrm{~mL}$ of ethanol (Merck) to make a $0.25 \%$ solution $(w / v)$. After $10 \mathrm{~min}$ in an ice bath, the suspension was sonified for $1 \mathrm{~min}$ at $20 \mathrm{kHz}$ (Ultrasonic Processor Model GE 50), resulting in an ethanolic extract of the original sample.

Semi-purification The ethanolic extract was filtered four times through acetate filters (Whatman, $0.45 \mu \mathrm{m}$ ) and the filtrate was evaporated in a rota-evaporator at $40^{\circ} \mathrm{C}$. The sample was then resuspended in $10 \mathrm{~mL}$ chloroform and placed in a separation funnel where $20 \mathrm{~mL}(2 \mathrm{~mL}$ each time) of deionized water at $\mathrm{pH} 3.3$ was used to wash the sample. During each wash, the sample was shaken manually for $90 \mathrm{~s}$, and the aqueous fraction was separated and saved. The aqueous fraction thus obtained, totaling

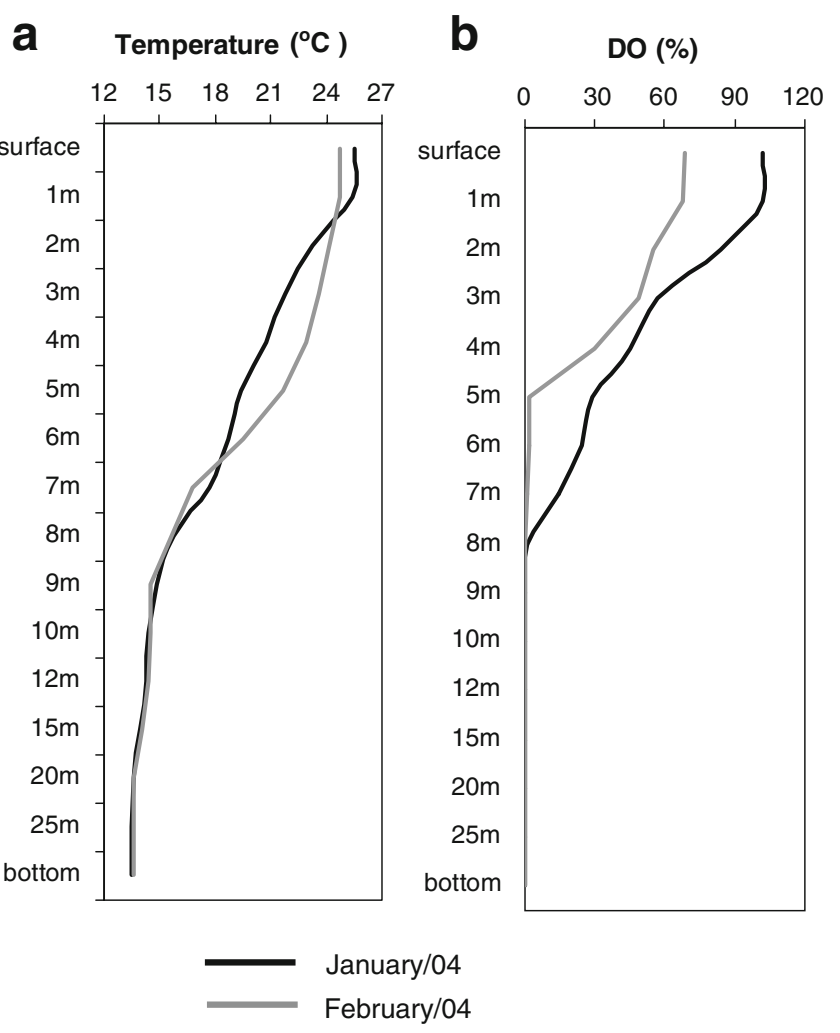

Fig. 2 Profile of water temperature (a) and dissolved oxygen (b) on January 11 and February 09, 2004, in Faxinal Reservoir 


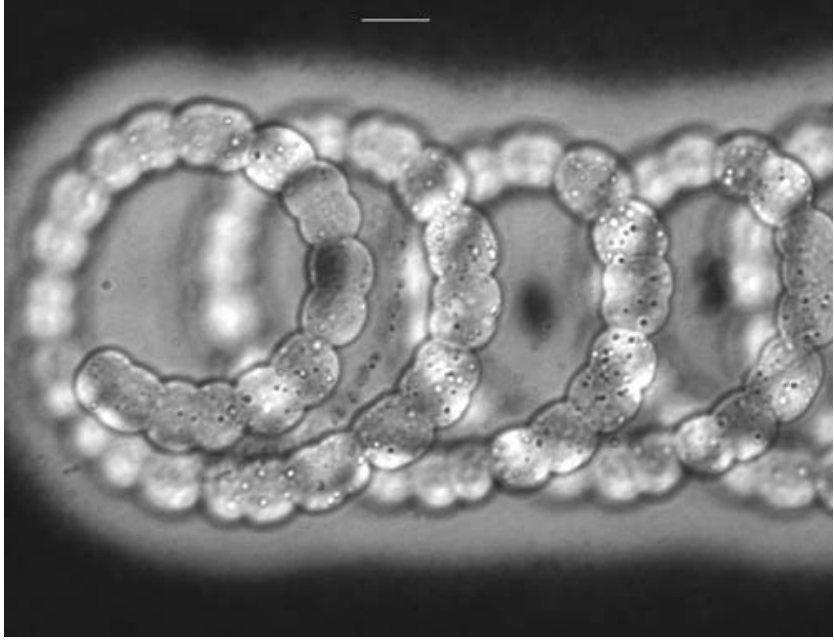

Fig. 3 Light micrographs of Anabaena crassa natural population showing regular coiled trichome and the mucilage. Scale bar $10 \mu \mathrm{m}$

$20 \mathrm{~mL}$, was then passed through a tC18 cartridge (Sep-Pak, Waters Milford, USA) previously activated by $10 \mathrm{~mL}$ absolute methanol and followed by $10 \mathrm{~mL}$ deionized water

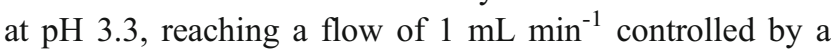
Peristaltic Pump.

Concentration The aqueous eluate was concentrated in a rota-evaporator at $40^{\circ} \mathrm{C}$ to a final volume of $2 \mathrm{~mL}$. This procedure was used in the enzyme assays, referring to the concentration of $50 \mathrm{mg} \mathrm{mL}^{-1}$.

Mouse bioassays were done using male Swiss albino mice (19-20 g body weight), through intraperitoneal injection $(1 \mathrm{~mL})$, corresponding to a dose of $1,000 \mathrm{mg} \mathrm{kg}^{-1}$ of lyophilized cyanobacteria powder extract/mouse body weight. Control animals were injected with $1 \mathrm{~mL} 0.9 \%$ $\mathrm{NaCl}_{2}, \mathrm{pH} 7.0$ and observed for at least $24 \mathrm{~h}$.

\section{Results}

During the study period (January and February 2004), the Faxinal Reservoir was strongly stratified, with higher
Table 1 Sample names, collection site and species identification

\begin{tabular}{lll}
\hline $\begin{array}{l}\text { Origin of } \\
\text { samples }\end{array}$ & $\begin{array}{l}\text { Collection } \\
\text { site }\end{array}$ & $\begin{array}{l}\text { Anabaena's } \\
\text { species }\end{array}$ \\
\hline $\begin{array}{l}\text { Caxias do Sul, } \\
\text { RS, Brazil-2004 }\end{array}$ & $\begin{array}{c}\text { Faxinal } \\
\text { Reservoir }\end{array}$ & $\begin{array}{l}\text { Anabaena crassa } \\
\text { (Lemmermann) } \\
\text { Komárková-Legnerová } \\
\text { Rio Grande, RS, }\end{array}$ \\
Brazil-1995 & Ornamental & $\begin{array}{l}\text { Anabaena spiroides } \\
\text { Klebahn }\end{array}$ \\
\hline
\end{tabular}

temperatures (up to $24^{\circ} \mathrm{C}$ ) in the epilimnion (Fig. 2a) and a deep anoxic hypolimnion (Fig. 2b). Mean densities of $A$. crassa (Fig. 3) during the bloom period were 71,750 cells $\mathrm{mL}^{-1}$ in January and 23,900 cells $\mathrm{mL}^{-1}$ in February. The decline of the bloom could be tracked through the weekly measurements of species density (Fig. 4).

Samples collected in the reservoir containing A. crassa (Table 1) in the second week of January 2004 contained cell densities between 55,000 and 65,000 cells $\mathrm{mL}^{-1}$. Samples of $A$. spiroides from Rio Grande, state of Rio Grande do Sul (RS) collected in 1995 had a cell density higher than 1 million cells $\mathrm{mL}^{-1}$.

Anticholinesterase activity was analyzed in both samples. The phytoplankton net sample of A. crassa from Caxias do Sul, RS showed 9\% AChE inhibition at an assay concentration of $50 \mathrm{mg} \mathrm{mL}^{-1}$ (Table 2), corresponding to $0.61 \mu \mathrm{g}$ of anatoxin-a(s) per gram of lyophilized powder. At these concentrations, symptoms of neurotoxicity or mortality were not observed in mouse bioassays.

In order to compare these assays, we also included and analyzed the sample of $A$. spiroides collected in 1995 in Rio Grande (Table 1), using different lyophilized Anabaena cell concentrations as a positive control (Table 3). Both Anabaena samples showed positive AChE inhibition; however, at the same concentration $\left(50 \mathrm{mg} \mathrm{mL}^{-1}\right)$, the $A$. spiroides samples from Rio Grande achieved $100 \%$ inhibition. In fact, this sample contains a very powerful AChE inhibitor factor, which at concentrations from below $6.2 \mathrm{mg} \mathrm{L}^{-1}$ of lyophilized bloom powder reached a level of
Fig. 4 Anabaena crassa density during January and February of 2004, in Faxinal Reservoir

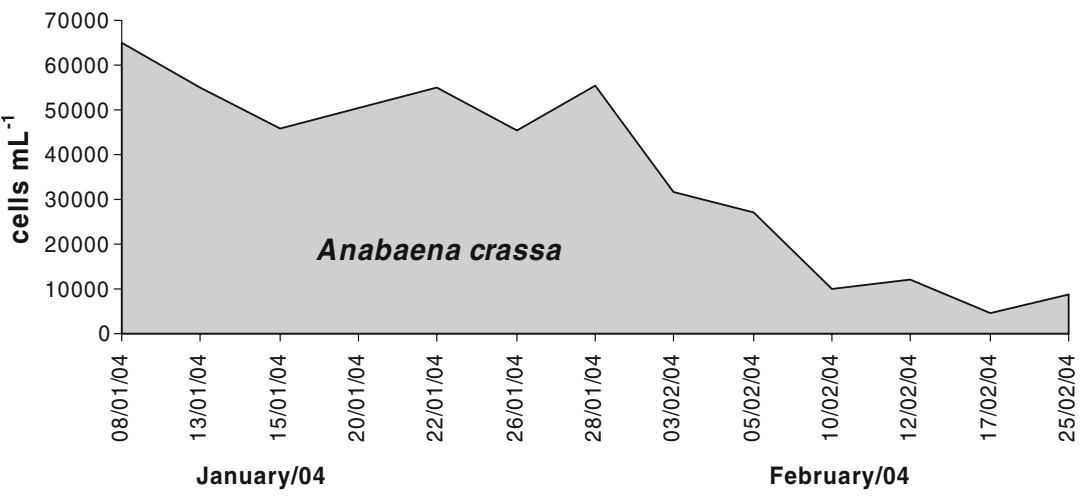


Table 2 AChE inhibition of the Caxias do Sul, RS (2004) sample at a single concentration of $50 \mathrm{mg} \mathrm{mL}^{-1}$

\begin{tabular}{lccc}
\hline Method & \% Inhibition & SD control & SD sample \\
\hline Indirect extraction & 1.6 & 4 & 3 \\
Direct extraction & 9 & 3 & 7 \\
\hline
\end{tabular}

$S D$ standard deviation

nearly $100 \%$ AChE inhibition. The so-called indirect or complete extraction procedure was used by Monserrat et al. (2001) and Barros et al. (2004) previously, and in the present study, we compared both extraction procedures. The values obtained in each extraction were described for the samples from Caxias do Sul, 2004 (Table 2) and Rio Grande, 1995 (Table 3). Higher AChE inhibition was observed in both samples obtained by the direct extraction method (Tables 2 and 3).

In the sample from Rio Grande, a dose-response correlation between sample concentration and AChE enzyme inhibition was apparent. Enzyme assays at decreasing concentrations revealed that a level as low as $12.5 \mathrm{mg} \mathrm{mL}^{-1}$ was still sufficient to produce almost $100 \% \mathrm{AChE}$ inhibition. Also, for all concentrations except $0.19 \mathrm{mg} \mathrm{mL}^{-1}$, higher AChE inhibitions were attained by applying the directextraction technique.

\section{Discussion}

The dominance of $A$. crassa in the summer of 2004 in Faxinal Reservoir constituted a steady state (equilibrium phase) of the population, as reported by Becker et al. (2008). The dominance of this species was strongly related to the water-column stratification, higher temperatures, and soluble reactive phosphorus (SRP) in the epilimnion. However, by means of the weekly sampling program, it was possible to track the decline of this bloom of $A$. crassa in February 2004.

The anatoxin-a(s) concentrations found in the samples of A. crassa were considered low, because the $\mathrm{LD}_{50}$ of the toxin is $20 \mu \mathrm{g} \mathrm{kg}^{-1}$ for mice, and no mortality occurred in the bioassays. The anatoxin-a inhibition factor present in the cells of $A$. crassa from Faxinal Reservoir is among those considered as very low by Barros et al. (2004).
Therefore, the blooms in 2004 posed no risk of contamination by anatoxin-a. Water from Faxinal Reservoir can still be considered not harmful, because of the low anatoxin-a(s) concentrations detected. However, this result is important, because it is the first record of anatoxin-a(s) from the species $A$. crassa. Continued monitoring of Faxinal remains essential, in view of the potential genetic and physiological variability of the species, and of the increase in the occurrence of $A$. crassa and other spiral forms of the genus in water-supply reservoirs, in southern Brazil. Subsequent to this study in 2004, A. crassa has not recurred in Faxinal Reservoir (SAMAE, personal communication) up to the time of publication of the present report.

Production of anatoxin-a(s)-like AChE inhibitors has been observed only in species of Anabaena, including Anabaena flos-aquae Brébisson ex Bornet et Flahault (Mahmood and Carmichael 1986) and A. lemmermannii Richter (Henriksen et al. 1997; Onodera et al. 1997). In Brazil, the few records of the occurrence of anatoxin-a(s) are restricted to single or mixed blooms of $A$. spiroides Klebahn (Monserrat et al. 2001; Molica et al. 2005; Yunes et al. 2003; Barros et al. 2004) and Anabaena planctonica Brunnthaler and Anabaena circinalis Rabenhorst ex Bonet and Flahault (Yunes et al. 2003; Barros et al. 2004).

Brazilian legislation for potable water (Brazil 2000, 2004) established the maximum concentration for microcystins $\left(1 \mu \mathrm{g} \mathrm{L}^{-1}\right)$ and recommended it for saxitoxins $\left(3 \mu \mathrm{g} \mathrm{L}^{-1}\right)$ and cylindrospermopsins $\left(15 \mu \mathrm{g} \mathrm{L}^{-1}\right)$. However, anatoxin-a(s) was not included. The stated reasons were that this toxin had not been reported from Brazilian drinking-water supplies and because of the lack of information about its toxicity levels, calculation of the risk from oral ingestion $\left(\mathrm{LD}_{50}\right)$, and possible difficulties in extraction of the toxin, as also revealed in the present report.

In order to confirm the effectiveness of this low AChE enzyme inhibition shown by the sample from Caxias do Sul taken in 2004, a positive control was applied using the Rio Grande 1995 sample previously studied by Monserrat et al. (2001) and Barros et al. (2004). Increasing concentrations of this sample were applied in order to produce a precise dose-response curve. An important step has been achieved in the process of recognizing the limitation of anatoxin-a(s) extraction. While several semipolar and nonpolar solvents were applied during sequential steps by the complete extraction procedure, it appeared that direct extraction

Table 3 AChE inhibition for the Rio Grande, RS, Brazil (1995) sample using sample concentrations from 100 to $0.19 \mathrm{mg} \mathrm{mL}^{-1}$

\begin{tabular}{|c|c|c|c|c|c|c|c|c|c|c|c|}
\hline $\begin{array}{l}\text { Sample concentration } \\
\left(\mathrm{mg} \mathrm{mL}^{-1}\right)\end{array}$ & 100 & 50 & 25 & 12.5 & 6.2 & 3.12 & 1.56 & 0.78 & 0.39 & 0.19 & $\mathrm{AChE}$ \\
\hline Indirect extraction & 30.2 & 12.4 & 10.5 & 1.9 & 0.5 & 0 & 0 & 0 & 0 & 0 & Inhibition (\%) \\
\hline Direct extraction & 100 & 100 & 100 & 99 & 91 & 69 & 43 & 13 & 0.8 & 0 & \\
\hline
\end{tabular}


using a single water sonification was more effective. The amount of the anti-AChE factor extracted was significantly higher under this condition. Although no effective tests of cyanobacterial extraction under different solvents are available, the reason for the increased efficiency appears to be that the direct method substantially reduces the losses of the anti-AChE factor because the sample is less manipulated.

After the passage of legislation in 2004, the occurrence of anatoxin-a(s) of A. spiroides Klebahn was recorded in Tapacurá Reservoir in northeastern Brazil (Molica et al. 2005), and in blooms of A. crassa in Faxinal Reservoir, as reported here. These records and the improvements in methodology will constitute a basis for future inclusion of this toxin in the requirements for analysis of this cyanotoxin in legislation for drinking-water quality control in Brazil and perhaps other countries.

Acknowledgments We are thankful to CT-Hidro/CNPq (Conselho Nacional de Desenvolvimento Científico e Tecnológico), CAPES (Coordenadoria de Aperfeiçoamento de Pessoal Superior), and SAMAE (Serviço Autônomo Municipal de Água e Esgoto de Caxias do Sul) for financial support. We also are grateful to the chemical engineer Fernanda B. Spiandorello, Graziela P. Monçani, and Renivo Girardi, technicians from SAMAE, for technical support; Dr. Vera R. Werner from Fundação Zoobotânica do Rio Grande do Sul for helpful discussion about species identification, and finally Dr. Janet W. Reid (JWR Associates) for the revision of the English text.

\section{References}

Azevedo SMFO, Evans WR, Carmichael WW, Namikoshi M (1994) First report of microcystins from a Brazilian isolate of the cyanobacterium Microcystis aeruginosa. J Appl Phycol 6:261265. doi:10.1007/BF02181936

Barros LPC, Monserrat JM, Yunes JS (2004) Determination of optimized protocols for the extraction of anticholinesterasic compounds in environmental samples containing cyanobacteria species. Environ Toxicol Chem 23:883-889. doi:10.1897/03-46

Becker V, Huszar VLM, Naselli-Flores L, Padisák J (2008) Phytoplankton equilibrium phases during thermal stratification in a deep subtropical reservoir. Freshw Biol 53:952-963. doi:10.1111/ j.1365-2427.2008.01957.x

Beyruth Z (2000) Periodic disturbances, trophic gradient and phytoplankton characteristics related to cyanobacterial growth in Guarapiranga Reservoir, São Paulo, Brazil. Hydrobiologia 424:51-65. doi:10.1023/A:1003944726346

Bouvy M, Nascimento SM, Molica RJR, Ferreira A, Huszar V, Azevedo SMFO (2003) Limnological features in Tapacurá reservoir (Northeast Brazil) during a severe drought. Hydrobiologia 493:115-130. doi:10.1023/A:1025405817350

Brazil (2000) Portaria $N^{\circ} 1469$ de 29 de dezembro de 2000: Normas de qualidade da água para consumo humano. Ministério da Saúde

Brazil (2004) Portaria $N^{\circ} 518$ de 25 de março de 2004: Portaria no. 518: Estabelece os procedimentos e responsabilidades relativas ao controle e vigilância da qualidade da água para consumo humano e seus padrões de potabilidade, e dá outras providências. Ministério da Saúde
Calijuri MC, Dos Santos ACA, Jati S (2002) Temporal changes in the phytoplankton community structure in a tropical and eutrophic reservoir (Barra Bonita, S.P. - Brazil). J Plankton Res 24:617634. doi:10.1093/plankt/24.7.617

Carmichael WW (1992) Cyanobacteria secondary metabolites - the cyanotoxins. J Appl Bacteriol 72:445-459

Carmichael WW, Falconer IR (1993) Diseases related to freshwater blue-green algal toxins, and control measures. In: Falconer IR (ed) Algal toxins in seafood and drinking water. Cambridge Academic Press, Cambridge, pp 187-209

Carmichael WW, Azevedo SMFO, An JS, Molica RJR, Jochimsen EM, Lau $S$ et al (2001) Human fatalities from cyanobacteria: chemical and biological evidence for cyanotoxins. Environ Health Perspect 109:663-668. doi:10.2307/3454781

Codd GA, Ward CJ, Bell SG (1997) Cyanobacterial toxins: ocurrence, modes of action, health effects and exposure routes. In: Seiler JP, Vilanova E (eds) Archives of toxicology. Springer, Berlin, pp 399-410

Colvara WA (2005) Desenvolvimento e implantação de método para análise de anatoxina-a em amostrais ambientais. Master Dissertation, Programa de Pós-Graduação em Oceanografia Física, Química e Geológica, Fundação Universidade de Rio Grande, 92 p

Cook WO, Beasley VR, Lovell RA, Dahlem AM, Hooser SB, Mahmood NA et al (1989) Consistent inhibition of peripheral cholinesterases by neurotoxins from the freshwater cyanobacterium Anabaena flos-aquae: studies of ducks, swine, mice and a steer. Environ Toxicol Chem 8:915-922. doi:10.1897/1552-8618 (1989)8[915:CIOPCB]2.0.CO;2

Ellman GL, Courtney KO, Andres V, Featherstone RM (1961) A new and rapid colorimetric determination of acetylcholinesterase activity. Biochem Pharmacol 7:88-96. doi:10.1016/0006-2952 (61) $90145-9$

Ferrão-Filho AS, Soares MC, Magalhães VF, Azevedo SMFO (2009) Biomonitoring of cyanotoxins in two tropical reservoirs by cladoceran toxicity bioassays. Ecotoxicol Environ Saf 72:479489. doi:10.1016/j.ecoenv.2008.02.002

Frizzo EE, Becker V, Spiandorello FB, Girardi R, Yunes JS (2004) Implantação do monitoramento fitoplanctônico, com ênfase em cianobactérias e cianotoxinas, nos mananciais de abastecimento do município de Caxias do Sul, RS. In Anais VIII Exposição de experiências municipais em saneamento $/ 34^{\mathrm{a}}$ Assembléia Nacional da ASSEMAE. ASSEMAE, Caxias do Sul, pp 421-424

Henriksen P, Carmichael WW, An J, Mostrup Ø (1997) Detection of an anatoxin-a(s)-like anticholinesterase in natural blooms and cultures of cyanobacteria/blue-green algae from Danish lakes and in the stomach contents of poisoned birds. Toxicon 35:901-913. doi:10.1016/S0041-0101(96)00190-0

Huszar VLM, Silva LHS, Marinho MM, Domingos P, Sant'anna CL (2000) Cyanoprokariota assemblages in eight productive tropical Brazilian waters. Hydrobiologia 424:67-77. doi:10.1023/ A:1003996710416

Kamárková-Legnerová J, Cronberg G (1992) New and recombined filamentous Cyanophytes from lakes in South Scania, Sweden. Arch Hydrobiol. Algol Stud 67:21-31

Komárek J, Anagnostidis K (1989) Modern approach to the classification system of cyanophytes, 4: Nostocales. Arch Hydrobiol. Algol Stud 56:247-345

Köppen W (1936) Das geographische System der Klimate-Handbuch der Klimatologie, $1^{\circ}$ vol., part C. Berlin: Gebr. Bornträger

Lagos N, Onodera H, Zagatto PA, Andrinolo D, Azevedo SMFO, Oshima Y (1999) The first evidence of paralytic shellfish toxins in the freshwater cyanobacterium Cylindrospermopsis raciborskii, isolated from Brazil. Toxicon 37:1359-1373. doi:10.1016/ S0041-0101(99)00080-X

Lund JWG, Kipling C, Lecren ED (1958) The inverted microscope method of estimating algal number and the statistical basis of 
estimating by counting. Hydrobiologia 11:143-170. doi:10.1007/ BF00007865

Mahmood NA, Carmichael WW (1986) The pharmacology of anatoxin-a (s), a neurotoxin produced by the freshwater cyanobacterium Anabaena flos-aquae NRC 525-17. Toxicon 24:425-434. doi:10.1016/0041-0101(86)90074-7

Mahmood NA, Carmichael WW, Pfahler D (1988) Anticholinesterase poisonings in dogs from a cyanobacterial (blue-green algae) bloom dominated by Anabaena flos-aquae. Am J Vet Res 49:500-503

Matsunaga S, Moore RE, Niemczura WP, Carmichael WW (1989) Anatoxin-a(s), a potent anticholinesterase from Anabaena flosaquae. J Am Chem Soc 111:8021-8023. doi:10.1021/ja00202a057

Matthiensen A, Beattie KA, Yunes JS, Kaya K, Codd GA (2000) [DLeu1] Microcystin-LR, from the cyanobacterium Microcystis RST 9501 and from a Microcystis bloom in the Patos Lagoon estuary Brazil. Phytochemistry 55:383-387. doi:10.1016/S00319422(00)00335-6

Minillo A, Ferreira AHF, Yunes JS (2000) Detecção de microcistina em florações de Microcystis aeruginosa no estuário da Lagoa dos Patos, RS, entre 1997 e 1998. Atlantica 22:81-93

Molica RJR, Oliveira EJA, Carvalho PVVC, Costa ANSF, Cunha MCC, Melo GL et al (2005) Occurrence of saxitoxins and an anatoxin-a(s)-like anticholinesterase in a Brazilian drinking water supply. Harmful Algae 4:743-753. doi:10.1016/j.hal.2004.11.001

Monserrat JM, Yunes JS, Bianchini A (2001) Effects of Anabaena spiroides (Cyanobacteria) aqueos extracts on the Aceltycholinesterase activity of aquatic species. Environ Toxicol Chem 20:1228-1235. doi:10.1897/1551-5028(2001)020<1228: EOASCA $>2.0 . \mathrm{CO} ; 2$

Onodera H, Oshima Y, Henriksen P, Yasumoto T (1997) Confirmation of anatoxin-a(s), in the cyanobacterium Anabaena lemmermannii, as the cause of bird kills in Danish lakes. Toxicon 35:1645-1648. doi:10.1016/S0041-0101(97)00038-X
Rapala J (1998) Toxin production by freshwater cyanobacteria: effects of environmental factors. PhD Thesis. University of Helsinki, Helsinki

Sant'Anna CL, Azevedo MTP (2000) Contribution to the knowledge of potentially toxic cyanobacteria from Brazil. Nova Hedwigia 71:359-385

Sotero-Santos RB, Carvalho EG, Dellamano-Oliveira MJ, Rocha O (2008) Occurence and toxicity of an Anabaena bloom in a tropical reservoir (Southeast Brazil). Harmful Algae 7:590-598. doi:10.1016/j.hal.2007.12.017

Uhelinger V (1964) Étude statistique des méthodes de dénobrement planctonique. Arch Sci 17:121-123

USEPA Ambient Water Quality Criteria Recommendations (2001) Information supporting the development of state and tribal nutrient criteria. Lakes and Reservoirs in Nutrient Ecoregion XIV, Office of Water 4304. US Environmental Protection Agency, Washington

Utermöhl H (1958) Zur vervollkommung der quantitativen phytoplankton-methodik. Mitteilungen der internationale Vereinigung fürTheoretische und Angewandte Limnologie 9:1-38

Vieira JMS, Azevedo MTP, Azevedo SMFO, Honda RY, Corrêa B (2005) Toxic cyanobacteria and microcystin concentrations in a public water supply reservoir in the Brazilian Amazonia region. Toxicon 45:901-909. doi:10.1016/j.toxicon.2005.02.008

Whitton BA (1992) Diversity, ecology, and taxonomy of the Cyanobacteria. In: Mann NH, Carr NG (eds) Photosynthetic prokaryotes, chapter 1. Plenum, New York, pp 1-51

Yunes JS, Cunha NT, Proença LAO, Barros LP, Monserrat JM (2003) Cyanobacterial neurotoxins from Southern Brazilian freshwaters. Comments Toxicol 9:103-115. doi:10.1080/08865140302426

Yunes JS, Matthiensen A, Carneiro C, Oroski F, Becker V, Carvalho MC (2005) Florações de Cianobactérias Tóxicas: Mãos à obra ao problema. In: Marinho M, Roland F, Cesar D (eds) Lições de Limnologia. RiMa, São Carlos, pp 299-323 